\title{
Torn in the Flesh: Critical Discourse Analysis on Discriminatory Acts in West Sumatra
}

\author{
Agustina $^{1}$, Muhammad Adek ${ }^{1(*)}$
}

\begin{abstract}
1Dep. of Indonesian Literature, Faculty of Languages and Arts, Universitas Negeri Padang, Padang, Indonesia, (*) marximalize@fbs.unp.ac.id, agustina@fbs.unp.ac.id
\end{abstract}

\begin{abstract}
Discriminatory acts committed by certain parties against particular community or groups on the basis of gender, religion, race and certain orientations contributed greatly to the decline in the Democratic Index in West Sumatra province. Subsequentlt, this research aimed to examine further at how this is practiced and what motives lie behind these contra-democratic discourses. Comparative theory of discourse known as BREAK theory from Sawirman (2014) which is equipped with a micro-linguistic analysis procedure and interdisciplinary approach in specify the ideas contained in the discourse foundation was exercised as the grand theory in this article. The results of the analysis showed that the discriminatory act was performed by two parties. First is government officials and second coming from community groups. The first discourse provides the information about the "demonisation" of gender and minority groups based on cynicism towards women and marginalized groups. The second discourse shows an indication of the settlement of a crime case by the community caused by the habit of being hands off by the government. The combination of these two converging-discourses ultimately reinforces discriminatory sentiments that lead to an atmosphere of undemocratic governance in West Sumatra.
\end{abstract}

Keywords: Critical discourse analysis (CDA); discriminatory acts; Indonesian democracy index; West Sumatra government; break theory

\section{INTRODUCTION}

Since declaring its independence from European colonialists, the Indonesian government has confidently established democracy as its political system (Reeve, 1985). In practice, the journey of Indonesia's democracy experiences quite complicated and winding routes (Budiarjo, Sumiarso \& Utomo, 1994). Initially, the implementation of Indonesian democracy began with a hybrid system called Parliamentary Democracy (19501957), then transformed into Guided Democracy (19571965) a la Sukarno and then Indonesia fell into a critical democracy phase in Suharto's authoritarian regime (19661998) during 32 years of his leadership (Bourchier, 2015). After Suharto's resignation, Indonesia undertook a major overhaul (or reform in all fields) and began trying to practice a more transparent and open democracy even though it was still in the shadow of the ghosts of the New Order (Bunte \& Ufen, 2008).

After enjoying some good times and moajor improvement in the transition phase and receiving appreciation from various observers and scholars (Liddle \& Mujani, 2013; Künkler \& Stepan, 2013), the present-day reality in the practice of democracy in Indonesia shows a declining trend (Warburton \& Aspinall, 2017). Beginning in 2018, a study (EIU, 2018) reported that there had been the biggest downgrade in the Indonesian Democracy Index since the assessment began in 2006. Indonesia was at the lowest threshold in the "flawed democracy" category before falling into the "hybrid regime" (Power, 2018). This trend is in line with the findings of a survey conducted by Freedom in the World (Freedom House, 2019).

This setback can be seen from three sources: the reemergence of authoritarian populism from among the old castes in power in Indonesia (Zhang and McRae, 2015), the emergence of xenophobic and sectarian political brands (Bourchier, 2019), and continuing liberal deviations in the regulation of civil liberties (Mulia, 2019). The concepts above have been transformed into discriminatory actions and behavior in society. This behavior is shown by almost all groups, both from the level of the political elite to the grassroots. These acts of violence and intolerance target certain groups that are considered minorities and are vulnerable (Puspandari \& Meijknecht, 2015).

The Central Statistics Agency (hereinafter BPS) annually has the duty to monitor the development and situation of democracy in Indonesia through a study called the Indonesian Democracy Index (hereinafter IDI). Since 2009, this study has highlighted various realities of democracy that occur in all provinces around Indonesia. In the year of 2016 measurement, the level of democracy in Indonesia fell to the "Medium" category after always being 
in the "Good" category (Indonesian Democracy Index 2016, p.xii). This level reduction occurred in all aspects of democracy measured, namely civil liberties which reduced by 3.85 points (from 80.30 to 76.45 ), political rights decreased by 0.52 points (from 70.63 to 70.11 ), and democratic institutions which dropped by 4.82 points (from 66.87 to 62.5 ).

One of the provinces worthy of being highlighted in the 2016 IDI calculation is West Sumatra. They are the only province in the "Poor" category with a score of 54.41 among 33 other provinces. When it is compared with the downward trend from other provinces such as DKI Jakarta which was in turmoil due to political turmoil, the figures produced by the province of West Sumatra are quite surprising and difficult to accept. Then, what actually happens in West Sumatra's society? Why does the province, which is known for its philosophical wisdom and openness in society, occupy the worst position in IDI? These questions are equally important to answer the problems that occur in the realm of Indonesia's democracy as a whole.

Referring to the work procedures performed by BPS, then a linguistic study that is quite similar and methodologically equivalent to explain the above phenomenon is Critical Discourse Analysis. This analysis focuses its analysis on texts or similar texts that have influence in society (Kress \& Hodge, 1979; Fairclough, 1995, 1989; Leeuwen, 2005). Further, the texts of the mass media selected by BPS as a portrait of democracy (Street, 2010; McNair, 2012) can also be used as material objects in this study. Because, the news report text is believed to have the potential and capacity to record socio-political events that occur at the grassroots. Thus, the information and knowledge produced by the news text are comprehensive and the truth can be accounted for.

The mass media report from regional newspapers based in West Sumatra in this study are understood as a discourse. Then, Critical Discourse Analysis views discourse as a structure that is not value-free and neutral (Fowler, 2013: Van Leeuwen, 2008; Wodak, 2001). Then, Sawirman (2014) said that the neutrality of a discourse can be traced through linguistic behavior (forms), the messages contained in it (essence) and the motives that underlie its emergence (spirit). Sawirman offers a BREAK analytical framework as one of the most recent and comprehensive methods of analysis in understanding today's discourse. By applying a layered and integrated analysis like this, it is hoped that the dismantling of the Singgalang newspaper news text as a reflection of the reality of democracy in West Sumatra can be conducted.

\section{METHOD}

The main object of this study was sourced from Singgalang newspaper, a regional-level mass media circulating in West Sumatra. This printed newspaper was chosen as a material object in this study due to the similarity of perception in the methodology implemented by BPS to obtain the Democracy Index in West Sumatra province. The timeframe for newspaper publication is in the same way, from January 2016 to 31 December 2016 or one year of publication. With the similarity of data sources, deviations in the work process can be avoided to a minimum.

These news reportings were examined carefully by paying attention to the two (2) variables that matter in this research; first, discriminatory actions and/or statements carried out by regional officials and second, threats/acts of violence committed by community groups with SARA reasons. However, in the development of research, some of the limits outlined by BPS were expanded in order to obtain more comprehensive data. This integrated analysis procedure was considered still relevant to the methodology implemented by BPS which refers to Indicator 9 and Indicator 10

To interpret the data into a complete understanding, qualitative content analysis was preferred as the method of analysis. Qualitative content analysis has been known for a long time and is used as the main reference as a technique in data analysis in the form of text (Nandy \& Sarvela, 1997). To achieve an interpretation of the text data, then the analysis is focused on the characteristics of language by focusing on the content or contextual meaning of the text (Budd, Thorp, \& Donohew, 1967; Lindkvist, 1981; McTavish \& Pirro, 1990; Tesch, 1990).

The stages undertook in this study were systematic grouping process of coding and recognizing themes or patterns (Weber, 1990). In means, data were read word by word to obtain codes (Miles \& Huberman, 1994; Morse \& Field, 1995) by first underlining the exact words from the text that appear to capture key thoughts or concepts; and then approaching the text by making notes to draw impressions, thoughts, and initial analysis.

A limitation in implementing this methodology was that the amount of collected data found is very limited because the data reduction process has many prerequisites. For example, if news texts are found that do not meet the $5 \mathrm{~W}+1 \mathrm{H}$ requirement, then the data was excluded. In addition, the mass media coverage also has limitations in capturing every incident that occurs in the midst of the community so that the possibility of the emergence of data was increasingly limited.

\section{RESULTS AND DISCUSSION}

Findings in this Critical Discourse Analysis (CDA) with the device analysis of theory BREAK can be classified into several features. Each feature has its own purpose and between features have analytical relationship. This relationship indirectly reinforces the argument and deepens the analysis of the data. The following is the distribution of findings in the critical discourse analysis features in the BREAK theory:

Discourse Position

Within theory of BREAK, the Discourse Position feature aimed at categorizing group of discourses. Based on the data collected, there are two groups of selected discourse that would be compared. The Primary Discourse was discriminatory acts/statements performed by government officials; the Secondary one was Violence 
acts/threat conducted by the group of people (by reason of gender, ethnicity and unusual interest).

The parameters that would be used as a benchmark or separation of the discourse were based on the intensity of the discourse's occurence in the mass media news reporting. In this case, intensity implies how often the deeds happened in the midst of community and indicates its urgency. Thus, it is believed that one of the discourses that dominates the reporting will be the main reference in the analysis than the other discourse. The following table identifies the position of the discourse based on the parameters above:

Table 1. Identification of Discourse Positions

\begin{tabular}{|c|c|c|}
\hline $\begin{array}{c}\text { Discourse } \\
\text { position }\end{array}$ & Primary & Secondary \\
\hline $\begin{array}{c}\text { Based on the } \\
\text { intensity of the } \\
\text { news in the mass } \\
\text { media }\end{array}$ & $\begin{array}{c}\text { Discriminative } \\
\text { statements/acts by } \\
\text { government } \\
\text { officials }\end{array}$ & $\begin{array}{l}\text { Threats/acts of } \\
\text { violence } \\
\text { conducted by } \\
\text { group of } \\
\text { people }\end{array}$ \\
\hline
\end{tabular}

Discourse Configuration

After doing the categorization process, the next stage of analysis was to extricate of the structure of discourse or better known as the analysis of form. This process was conducted with the aim of obtaining information/knowledge/hidden messages contained in the form of textual discourse. This interpretation process started from the primary discourse and then continues with the secondary discourse.

a) Form

The linguistic formulation that has been identified from the Primary Discourse group which contains 'discriminatory statements of government officials' in the mass media text was hyperbole language style. Etymologically, hyperbole comes from the words huper means 'up' and balo means 'throw'. This style of language is used to exaggerate things from the actual situation. Utilization of hyperbole usually aims to increase the emotional arousal of readers and create emphases on something that is discussed (Carston \& Wearing, 2011). The occurance of hyperbole style in Primary discourse can be found in the following data.

1. Satpol PP Jaring 52 Wanita (S:10/2/19)

2. Empat Wanita Mabuk Diamankan (S:3/2/19)

3. Satpol PP Ringkus Seorang Mucikari dan Empat PSK (S:17/3/19)

$(\mathrm{S}: 2 / 5 / 19)$

4. Polisi Tangkap Tiga PSK dan Mucikari

Looking at patterns in the predicate function with verbs that fill it, then, interesting hypothesis will appear. The verbs are considered inappropriate to describe an event which involves humans as targeted objects or hyperbolic. Verb 'jaring'/nets should be intended for objects such as fish and the aquatic animal, verb 'ringkus'/catch refers to wild animals, verbs 'tangkap'/snare for hunted animals and and verbs 'amankan'/secure for disturbing objects. The presence of such Verb seems to 'nullify' humans from their position as respectable creation into objects that are not treated humanely.

Aside from using the hyperbole language style with the selection of Verbs that don't reflect humanity, also found some Primary discourse data using hyperbole with other perspective. Here are the data found:

5. Tujuh Anak Punk Diamankan Satpol PP

6. Tiga Waria Diamankan Satpol PP (S:23/3/19)

7. Masyarakat Diminta Waspada, Disinyalir Ada Asrama Khusus LGBT di Kota Padang (S:8/6/19)

The verb 'secured' appears twice following the Object functions of 'Anak Punk'/Punk teens and 'Waria/Transvestite'. This verb selection certainly causes excess emotional effects from the reader's side when reading the structure. This reflects the presence of a distinctive perspective in looking at these objects. In particular, both of these Objects are discredited groups in the midst of society (in a sense, not yet regulated in the Constitutional).

For secondary discourse groups that contain 'threats/acts of violence by community groups', the linguistic form that can be identified is euphemism. Etymologically, euphemism comes from the words eu(means good) and pheme (means words/speech) which when combined into 'good/lovely words'. In language used, euphemism is performed to avoid the unfavorable meaning of a reality by reducing, bend, change the point of view or hide the true meaning. This can be served to be polite and to hide things for certain considerations (Holder, 2002). The use of euphemisms in Secondary discourse can be found in the following data:

1. Lebaran, Pemuda Dua Nagari Nyaris Cakak Banyak (S:11/7/16)

2. Rusuh Tapal Batas Sijunjung-Dharmasraya $(\mathrm{S}: 30 / 7 / 16)$

In data (1), euphemisms are found in the structure of news reports through changing perspectives. In the details of the news that was collected, the cause of the dispute involving Pemuda Dua Nagari was the beating of a resident named Rifal (17) from the nearby Nagari. However, when it becomes a headline news, it is not raised proportionally. The structure instead changes the viewpoint into a celebration of the Eid Mubarak which can obscure the existence of an ethnic based violence that is happening in that district. The identical pattern applies to data (2).

Besides appearing in the form of euphemism, Secondary discourse also appears in the pattern of passivation. Passive forms are structures that have changed their order, especially the position exchange between the Subject and Object functions. In line with the form of euphemism, passivation can have an impact on the blurring of a particular function by highlighting other functions. The application can be found in the following data. 


\author{
3. Sengketa Tanah di Tiga Kecamatan, \\ Masyarakat dan Pejabat Sering Diteror (S:5/9/16) \\ 4. Kawanan Jambret Bonyok Dihajar Warga \\ (S:31/10/16)
}

Apart from the appearance of a passive structure, there is another relationship formed between the two clauses, the causal pattern. In data (3), the cause of the community and officials often being terrorized is sengketa tanah/land disputes. In data (4), the cause of the residents committing acts of violence is (the presence of) kelompok jambret/a group of snatchers. The close relationship between the two together emphasizes the object in question. Through this pattern as well, the Subject function is not very clear and the presence is not immense.

\section{b) Essence}

After analyzing the data to find the linguistic forms of the two discourses, Essence analysis aims to interpret data into a range of messages, ideas and meanings embedded in each discourse. Every discourse, even though it is in the same purpose, does not necessarily deliver the same message/idea. It is this variation of the message that must be found through the interpretation of the linguistic form. Therefore, the results of the analysis of the form which is the main foundation in the discovery of the essence of each discourse.

From the primary discourse in the form of hyperbole, there are two ideas that can be put forward. The first idea is the demonization of female gender (misogyny). From the first four data displayed, all objects that were targeted (usual women, drunk women and prostitutes) were female. The treatment received by the object is also described as totally inhumane and injuring the gender dignity of women as illustrated in the verb of nets, catch, snare, secure. This view certainly has an impact on lowering women's selfesteem and increasingly cornering women in society (Simons, 2001).

The second idea that emerges from the form of Primary discourse is discrimination towards minority and vulnerable groups. The marginal groups referred to in this context are 'anak punk' (5), 'waria' (6), and 'LGBT groups' (7). These three groups (until now) are considered as a threat to the general public in Indonesia (Badgett, Hasenbush \& Luhur, 2017). This is known from the choice of (P)Verbs that follow the Object, namely: secured (5-6) and alert (7). Such groups are classified as groups that are very vulnerable to experience injustice and should receive more attention from the government (Arivia \& Boangmanalu, 2015).

From secondary discourse in the form of euphemism, the message that can be captured is the underestimate of violence case. From the news reported, the residents seemed to practice vigilantism. This can be caused by the absence of government as a function of control and negotiation in the midst of society (Eilenberg, 2011). The still lack of supervision and law enforcement in the regions often leads to riots between ethnic and regions as in the data (1) and (2).
In other secondary discourse groups, the discourse of violence practiced by the community group arises with the idea that law enforcement is still weak in the community. As reflected in the data (3) and (4), the object affected by violence is the community whose rights have been impaired due to the law not functioning in the community. A group of people (the mafia, mob, paramilitary) can freely conduct surveillance to ordinary civil society (Cribb, 2000). Likewise, with the situation (allegedly) snatched by residents who have lost the right to presumption of innocence against him. The messages in the secondary discourse lead to a perspective that the practice of violence (physical and mental) by certain groups of people is still often found.

c) Spirit

The spirit contained in Primary discourse is genderbased cynicism. As can be seen from the results of the analysis of the essential features, actions of (extended arms) government officials such as Satpol PP and the Cops have a tendency that is strong enough to corner a certain gender (which is hierarchically) very weak in society such as female (Sen, 2002). In addition, these actions are also depicted with predicates categorized as hyperbolic verbs such as nets, catch, snare, and secure.

This implies the inhumane treatment of women represented by women, drunk women and commercial sex workers. In fact, to shape a democratic and developed country, the government should treat and empower women (Gallaway \& Bernasek, 2004) with more persuasive approaches, such as training, empowerment and so on.

Furthermore, the actions of government officials are described in Verbs which are somewhat different (but still in the same spirit) when dealing with other vulnerable groups. The group in question is a punk teens, transvestite and LGBT group. Verbs that are occured in the structure are secured and alert. As a group vulnerable to discriminatory treatment, these groups should also not be considered a threat in society. The repression of this group in the end implies the spirit of exclusivism.

In secondary discourse, the spirit that can be raised is the hands-off practice of government. In data (1) and (2), the riots that arose between residents did not get enough anticipation from the government. This has an impact on the fall of the victims and even the spread of the dispute. The government should pay more attention to sensitive time/space such as nearing Eid Mubarak or border areas so as to minimize the raise of conflicts. In other data, the absence of government oversight and law enforcement functions in the midst of the community causing some groups of people to suffer physical damages such as suspected snatches and mental losses such as disputed groups. Such losses and disadvantages should be anticipated in realizing a democratic and safe government. Type of Discourse Movement

Based on the results of data analysis on the configuration features (essence-spirit-essence) of the comparing discourse, the types of movements of the two discourses above can be illustrated through the following table. 
Table 2. Types of Primary and Secondary Discourse Movements

\begin{tabular}{ccc}
\hline Essence & $\begin{array}{c}\text { Primary } \\
\text { Discourse }\end{array}$ & $\begin{array}{c}\text { Secondary } \\
\text { Discourse }\end{array}$ \\
\hline & $\begin{array}{c}\text { Demonization } \\
\text { of female } \\
\text { gender and } \\
\text { minority groups }\end{array}$ & $\begin{array}{c}\text { Settlement of crime } \\
\text { cases by the Govs }\end{array}$ \\
\hline Spirit & $\begin{array}{c}\text { Gender and } \\
\text { group-based } \\
\text { cynicism }\end{array}$ & $\begin{array}{c}\text { Hands-off practice } \\
\text { by the Govs }\end{array}$ \\
\hline Result & $\begin{array}{c}\text { undemocratic } \\
\text { atmosphere }\end{array}$ & $\begin{array}{c}\text { undemocratic } \\
\text { atmosphere }\end{array}$ \\
\hline $\begin{array}{c}\text { Discourse } \\
\text { movement }\end{array}$ & $\begin{array}{c}\text { Convergent } \\
(\mathrm{KO})\end{array}$ & $\begin{array}{c}\text { Convergent } \\
(\mathrm{KO})\end{array}$ \\
\hline
\end{tabular}

Based on the table above, the general types of discourse movements identified are convergent. Both primary and secondary discourses have movements that are interrelated to one another so that it belongs to the type of convergent-convergent (KO-KO). The characteristics of the movements of these two discourses are cooperative and united. That is, the essence and enthusiasm contained in each form of discourse have a common goal and support each other.

\section{CONCLUSIONS}

In relation to discriminatory acts/utterances recorded in the mass media news texts in West Sumatra, hence there are two groups of discourses that develop, namely discriminatory actions/statements by regional officials and the second is threats/acts of violence by community groups. Both discourses have their own particular patterns and are not similar as each other.

Behind the pattern of hyperbolic structure in primary discourse, the deeds of regional officials (which in this case are represented by the apparatus) often reflect the injustice for ordinary people. This is made worse through demonization of minority and vulnerable groups in the heart of society. Until finally this action strengthened cynicism towards the opressed group.

In secondary discourse, the pattern of euphemism implies that there are undervaluation cases of crime and violence performed by certain groups of people rooted in hands off practices from the local government. As a result, a series of results of discriminatory actions hold by local government officials and violence by a group of people increasingly distance the province of West Sumatra with the category of government that is democratic and fair.

\section{ACKNOWLEDGMENTS}

This research and article were funded by Ministry of Research, Technology and Higher Education DRPM through DIPA-042.06.1.401516/2019. For this reason, the thanks go to the Minister and Director General of DRPM through the Chancellor and Chairperson of LP2M of Universitas Negeri Padang.

\section{REFERENCES}

[1] Arivia, G. and A. G. Boangmanalu. (2015). "When the state is absent: A study of LGBT community in Jakarta." Jurnal Perempuan, 20(4). 367-376.

[2] Badan Pusat Statistik. (2017). Berita resmi statistik, No. 84/09/th. XX, 14 September 2017. Jakarta.

[3] Badgett, M. V. L., Hasenbush, A., \& Luhur, W. E. (2017). LGBT exclusion in Indonesia and its economic effects. Williams Institute, UCLA School of Law.

[4] Bourchier, D. (2015). Illiberal democracy in Indonesia: The ideology of the family state. Routledge.

[5] . (2019): Two decades of ideological contestation in Indonesia: From democratic cosmopolitanism to religious nationalism, Journal of Contemporary Asia, DOI: 10.1080/00472336.2019.1590620.

[6] Budd, R. W., Thorp, R. K., \& Donohew, L. (1967). Content analysis of communications. New York: Macmillan.

[7] Budiarjo, M., Sumiarso, Y., \& Y. P. Utomo. (1994). Demokrasi di Indonesia: Demokrasi parlementer dan demokrasi Pancasila. Gramedia Pustaka Utama

[8] Bunte, M., \& Ufen, A. (Eds.). (2008). Democratization in post-Suharto Indonesia. Routledge.

[9] Carston, R., \& Wearing, C. (2011). Metaphor, hyperbole and simile: A pragmatic approach. Language and Cognition, 3(2), 283-312.

[10]Cribb, R. (2000). From Petrus to Ninja: death squads in Indonesia. In Death Squads in Global Perspective (p.181-202). Palgrave Macmillan.

[11]Economost Intelegence Unit. (2018). World Democracy Report (2018). Retrieved from https://www.eiu.com/topic/democracy-index

[12] Eilenberg, M. (2011). Flouting the law: Vigilante justice and regional autonomy on the Indonesian border. Austrian Journal of South-East Asian Studies, 4(2), 237-253.

[13] Fairclough, N. (1989) Language and power. Longman.

[14]_ (1995) Critical Discourse Analysis. Longman.

[15]Fowler, R. (2013). Language in the news: Discourse and ideology in the press. Routledge.

[16] Freedom House (2019). Democracy in retreat: Freedom in the world 2019. https://freedomhouse.org/report/freedomworld/freedom-world-2019/democracy-in-retreat

[17] Gallaway, J. H., \& Bernasek, A. (2004). Literacy and women's empowerment in Indonesia: 
implications for policy. Journal of economic issues, 38(2), 519-525.

[18] Holder, R. W. (2002). How not to say what you mean: A dictionary of euphemisms. Oxford university press.

[19] Kress, G., \& Hodge, R. (1979). Language as ideology. Routledge.

[20] Künkler, M., \& Stepan, A. (2013). Democracy and Islam in Indonesia. New York: Columbia University Press.

[21] Liddle, R. W., \& Mujani, S. (2013). Indonesian democracy: From transition to consolidation. In A. Stepan \& M. Künkler (Eds.), Democracy and Islam in Indonesia (pp. 24-50). New York: Columbia University Press.

[22] Lindkvist, K. (1981). Approaches to textual analysis. In K.E.Rosengren (Ed.), Advances in content analysis (pp. 23-41). Sage.

[23] McNair, B. (2012). Journalism and democracy: An evaluation of the political public sphere. Routledge.

[24] McTavish, D. G., \& Pirro, E. B. (1990). Contextual content analysis. Quality and Quantity, $24,245-265$

[25] Menchik, J. (2019): Moderate muslims and democratic breakdown in Indonesia, Asian Studies Review, DOI: 10.1080/10357823.2019.1627286

[26] Miles, M.B., \& Huberman, A.M. (1994). Qualitative data analysis: An expanded sourcebook. Sage

[27] Morse, J. M., \& Field, P. A. (1995). Qualitative research methods for health professionals (2nd ed.). Sage.

[28] Mulia, S. M. (2019). Potret Kebebasan Berkeyakinan di Indonesia: Sebuah refleksi masa depan kebangsaan Indonesia. NUSANTARA: Journal for Southeast Asian Islamic Studies, 14(2), 117-125.

[29] Nandy, B.R., \& Sarvela, P. D. (1997). Content analysis reexamined: A relevant research method for health education. American Journal of Health Behavior, 21, 222-234.

[30] Power, T. P. (2018). Jokowi's authoritarian turn and Indonesia's democratic decline. Bulletin of Indonesian Economic Studies, 54(3), 307-338.

[31] Puspandari, N., \& Meijknecht, M. D. A. (2015). The increasing intolerance towards religious minorities in Indonesia: Have the existing laws been protecting or marginalising them? Unpublished Master's Thesis. Netherlands: Tilburg Law School, Tilburg University. Available online also at: http://arno. uvt. nl/show. cgi.

[32] Reeve, D. (1985). Golkar of Indonesia: An alternative to the party system. Oxford University Press.
[33] Sawirman. (2014). E-135 Reader: media meliput teror (edisi Osama bin Laden). Padang: Pusat Studi Ketahanan Nasional dan Universitas Andalas.

[34] Sen, K. (2002). Indonesian women at work: Reframing the subject. In Gender and power in affluent Asia (pp. 49-76). Routledge.

[35] Simons, M. A. (2001). Beauvoir and The Second Sex: Feminism, race, and the origins of existentialism. Rowman \& Littlefield Publishers.

[36] Street, J. (2010). Mass media, politics and democracy. Macmillan International Higher Education.

[37] Tesch, R. (1990). Qualitative research: Analysis types and software tools. Falmer.

[38] Warburton, E., \& Aspinall, E. (2017, 17 August). Indonesian democracy: From stagnation to regression? The Strategist. Retrieved from https://www.aspistrategist.org.au/indonesiandemocracy-stagnation-regression/

[39] Van Leeuwen, T. (2008). Discourse and practice: New tools for critical discourse analysis. Oxford University Press.

[40] Weber, R. P. (1990). Basic content analysis. Sage.

[41] Wodak, R. (2001). What CDA is about-a summary of its history, important concepts and its developments. Methods of critical discourse analysis, 1, 1-13.

[42]Zhang, D., \& D. McRae. (2015). Policy diffusion: The replication of Jamkesda and Bosda. Jakarta: Australia Indonesia Partnership for Decentralisation. 